\title{
ZASNOVA GEOGRAFSKEGA PRISTOPA K IZDELAVI STROKOVNIH PODLAG ZA PROSTORSKO NAČRTOVANJE V POREČJIH
}

\author{
Andrej Draksler*, mag., dr. Simon Kušar** \\ *Zgornje Bitnje I4a, SI-4209 Žabnica \\ **Oddelek za geografijo, Filozofska fakulteta Univerze v Ljubljani \\ Aškerčeva 2, SI-I 000 Ljubljana \\ e-pošta: andrej.draksler27@gmail.com, simon.kusar@ff.uni-lj.si
}

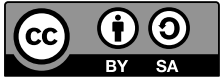

Izvirni znanstveni članek

COBISS 1.01

DOI: $10.4312 /$ dela.49.37-59

\section{Izvleček}

Kljub načelnemu približevanju upravljanja z vodami ter prostorskega načrtovanja v Vodni direktivi (2000) poteka izdelava načrtov upravljanja voda brez upoštevanja širših razvojnih dejavnikov v prostoru. V prispevku predlagamo celovitejši oziroma geografski pristop k izdelavi strokovnih podlag kot izhodišče za prostorsko načrtovanje v porečjih, in sicer s povezavo DPSIR modela in strokovnih analiz pri prostorskem načrtovanju. Tako smo povezali okoljski vidik načrtovanja razvoja porečij s širšim razvojnim vidikom. Predlagani pristop smo preverili in ovrednotili na primeru porečja reke Kokre v Sloveniji.

Ključne besede: prostorsko načrtovanje, trajnostni prostorski razvoj, strokovne podlage, regionalna analiza, upravljanje porečij, DPSIR model, porečje, Kokra, Slovenija

\section{CONCEPT OF THE GEOGRAPHICAL APPROACH TO PROFESSIONAL ANALYSIS IN RIVER BASIN SPATIAL PLANNING}

\begin{abstract}
Despite a general harmonization of the water management and spatial planning in the Water Directive (2000), the preparation of the river basin management plans takes place without considering the wider developmental factors in the area. In the article, we propose a more comprehensive or geographical approach to professional analysis relevant for river basin spatial planning by combining the DPSIR model with professional analysis in spatial planning. Thus, we are linking the environmental aspect of river basin planning with a broader developmental aspect. The proposed approach was implemented and evaluated in the case of the Kokra river basin in Slovenia.
\end{abstract}

Keywords: spatial planning, sustainable spatial development, professional basis, regional analysis, river basin management, DPSIR model, river basins, Kokra, Slovenia 


\section{UVOD}

Človekovo delovanje vpliva na podobo in funkcijo prostora, obenem pa prostor s svojimi danostmi in omejitvami usmerja človekove dejavnosti in prostorski razvoj. Prostorsko načrtovanje skuša ob upoštevanju naravnih razmer, družbenih značilnosti območja in vizij o prihodnjem razvoju zagotavljati enakomeren gospodarski, družbeni in prostorski razvoj. Eden ključnih korakov pri prostorskem načrtovanju je določitev ustreznega območja načrtovanja.

Prostorsko načrtovanje je najučinkovitejše v naravnogeografsko in družbenogeografsko zaokroženih prostorskih enotah, ki omogočajo enakovredno upoštevanje vseh prostorskih elementov in dejavnikov ter procesov. Porečje kot enota za prostorsko načrtovanje omogoča takšen celostno zasnovan razvoj, ki je sestavljen iz upravljanja z okoljskimi, gospodarskimi, človeškimi in drugimi viri (Hagget, 1972; Mather, Chapman, 1995; Petts, Bravard, 1996). Zato prostorsko načrtovanje v okviru porečij predstavlja eno od možnosti za doseganje trajnostnega prostorskega razvoja.

Najpogostejši vzrok za načrtovanje na ravni porečij je zagotavljanje kakovosti vodnih virov (Newson, 2009). Toda številne izkušnje kažejo, da upravljanje z vodnimi viri ne sme biti ločeno od celovitega načrtovanja razvoja, temveč ga je smiselno vključiti v obstoječe sisteme upravljanja s prostorom (Bricelj, 2007; Kidd, Shaw, 2007; Prah, 2012). Čeprav gre za tradicionalno dva ločena sektorja, je upravljanje z vodnimi viri neločljivo povezano s prostorskim načrtovanjem in ju je smiselno povezati in okrepiti (Woltjer, Al, 2007; Grindlay in sod., 2011). Povezanost je pomembna za obe strani: upravljanje voda je odvisno od prihodnjih vodnih potreb in dinamike prostorskega razvoja, na drugi strani pa je naloga prostorskih načrtovalcev, da upoštevajo vplive načrtovanega prostorskega razvoja na vodne vire in spodbujajo njihovo trajnostno rabo. V nasprotnem primeru postanejo vodni viri zaradi poslabšanja kakovosti ali dostopnosti omejitveni dejavnik prostorskega razvoja (Carter, 2007; Grindlay in sod., 2011).

Evropska Vodna direktiva iz leta 2000 (Direktiva Evropskega parlamenta ..., 2000) je uvedla nov načrtovalski pristop pri upravljanju s porečji. Vodna direktiva predvideva izdelavo načrtov upravljanja porečij (v nadaljevanju NUV). To je nacionalni dokument, ki opredeljuje mehanizme za vodenje politike na področju voda skladno z evropsko Vodno direktivo. V njem so predvideni ukrepi, s katerimi naj bi dosegli cilje direktive (Rejec Brancelj, Dobnikar Tehovnik, Uhan, 2011). Vsak NUV mora poleg analize obremenjevanja vodnih virov izvesti tudi analizo vpliva človekovih dejavnosti na površinske in podzemne vode z uporabo DPSIR modela (Driving forces - Pressures - States - Impacts Responses). Direktiva s tem povezuje upravljanje voda in prostora (Howe, White, 2002).

Kljub načelnemu približevanju vodnega upravljanja ter prostorskega načrtovanja v Vodni direktivi (Direktiva Evropskega parlamenta ..., 2000) pa praksa (npr. Načrt upravljanja vodnega območja Donave - Danube River Basin ..., 2009; Danube River Basin ..., 2015) kaže, da upravljanje z vodnimi viri poteka brez zadostnega upoštevanja ostalih elementov v prostoru. Takšen pristop je $\mathrm{z}$ vidika doseganja trajnostnega prostorskega razvoja porečij problematičen, saj s sektorskim pogledom ne upošteva dejstva, da prostorski procesi v porečju pomembno zaznamujejo količino in kakovost vode. $\mathrm{V}$ 
prispevku zato za povezavo med pristopom k upravljanju voda in prostorskim načrtovanjem predlagamo geografski pristop k izdelavi strokovnih podlag kot možno izhodišče za celovitejši analitično-geografski in prostorsko-načrtovalski pogled na problematiko trajnostnega prostorskega razvoja v porečjih. Predlagani pristop povezuje načrtovanje upravljanja voda (DPSIR model) in strokovne analize v prostorskem načrtovanju. S tem želimo na metodološki ravni doseči tesnejšo povezanost upravljanja voda $s$ širšim razvojnim vidikom. Predlagani geografski pristop smo preverili in ovrednotili na primeru porečja reke Kokre v Sloveniji.

\section{TEORETIČNA IZHODIŠČA}

Predlog celovitejšega, geografskega pristopa k izdelavi strokovnih podlag, potrebnih za prostorsko načrtovanje $\mathrm{v}$ porečjih za doseganje njihovega trajnostnega prostorskega razvoja, temelji na povezavi pristopa $\mathrm{k}$ upravljanju voda in pristopov $\mathrm{k}$ izdelavi analiz, potrebnih za izdelavo strokovnih podlag pri prostorskem načrtovanju. V nadaljevanju zato postavljamo teoretične temelje predlaganemu geografskemu pristopu, in sicer z opredelitvijo porečij kot prostorsko-načrtovalskih enot, ki lahko služijo kot prostorska enota za doseganje trajnostnega prostorskega razvoja, prikazom osnovnih značilnosti DPSIR modela ter predstavitvijo sistema prostorskega načrtovanja v Sloveniji, s čimer nakažemo na uporabno vrednost predlaganega geografskega pristopa.

\section{I Porečje kot prostorsko-načrtovalska enota}

Trajnostni prostorski razvoj pomeni uravnotežen napredek na okoljskem, gospodarskem, kulturnem in socialnem področju. Prostorska členitev ozemlja, v katerem potekajo prizadevanja za njegovo doseganje, mora biti zato prilagojena zmogljivostim okolja, gospodarski sestavi, poselitvi, vplivnim območjem središč, lokalni ter regionalni pripadnosti prebivalcev, omogočati mora varčno rabo naravnih in drugih endogenih virov ter s tem njihovo obnavljanje in razpoložljivost za prihodnje generacije (Unwin, 1997).

Pri opredeljevanju porečij so v ospredju hidrogeografski kriteriji. Porečje je tako praviloma opredeljeno na osnovi rečne mreže, vodozbirnega območja glavne reke in usmeritve vodnega toka, ločenega od sosednjih z višje ležečimi topografskimi razvodnicami (Blij, Muller, 1993; cit. v Plut, 1999).

Porečja s svojimi naravnogeografskimi značilnostmi sooblikujejo prostorsko organiziranost družbe, saj jih zaznamujejo gravitacijski tokovi, ki pogosto sovpadajo z družbenimi, na primer s prebivalstvenimi ali prometnimi tokovi. Porečja zato vplivajo na poselitveni vzorec: lokacijo in funkcijo naselij ter oblikovanje gravitacijskega zaledja središčnih naselij (Plut, 1999), značilnosti prometne mreže ter rabo vodnih virov, vodooskrbo in čiščenje odplak.

Tradicionalni regionalizacijski pristop se je preveč osredotočal na industrijske dejavnosti in urbano družbo (Plut, 1999). Ker porečja označuje povezanost fizičnogeografskih značilnosti in organiziranosti človeške družbe, so z geografskega vidika, ki podčrtava celovitost, povezanost in medsebojno součinkovanje (Vrišer, 1992), primerna prostorska 
enota, v kateri lahko potekajo prizadevanja za trajnostno gospodarjenje z naravnimi (vodni viri, prsti, ekosistemi), urbanimi (industrija, mesta) in človeškimi viri (izobraževanje; Mather, Chapman, 1995; Newson, 2009).

Osredotočenost na porečja je tudi priložnost za preseganje omejitev, ki jih prinaša normativno urejen sistem prostorskega načrtovanja (Woltjer, Al, 2007; Grindlay in sod., 2011). Administrativne meje, znotraj katerih poteka prostorsko načrtovanje, so razdelile porečja na manjše dele, kar onemogoča celovito reševanje aktualnih prostorskih in okoljskih izzivov, kot so oskrba z vodnimi viri, čiščenje odpadne vode, ogroženost zaradi poplav in drugih naravnih nesreč, industrijskih nesreč, plovba ter načrtovanje zelene infrastrukture. Reševanje tovrstnih problemov je namreč uspešnejše v okviru večje prostorske enote, ki v celoti zaobjame problemsko območje (Kušar, 2006). Za načrtovanje niso primerna samo velika porečja (na primer Tennessee, Delaware, Fraser, Ren, Donava) ampak tudi manjša porečja (Gardiner, Thompson, Newson, 1994; Jones, 1997; Newson, 2009), saj takšen pristop pomembno prispeva k napredku na ravni večjega porečja (Siegel, Schabl, 2008).

\subsection{Upravljanje voda}

Pomemben prispevek k trajnostnemu prostorskemu razvoju porečij je evropska Vodna direktiva (Direktiva Evropskega parlamenta ..., 2000), ki je uvedla nov načrtovalski pristop upravljanja s porečji. Vodna direktiva predvideva izdelavo NUV. To je »dokument o upravljanju voda na vodnem območju, s poudarkom na stanju, ciljih in načrtovanih programih stroškovno učinkovitih ukrepov na vodnih telesih za doseganje ciljev upravljanja voda« (Bizjak, 2008, str. 103).

V evropski načrtovalski pristop na področju voda je vključen tudi DPSIR model (poimenovan tudi kot okvir, orodje, pristop, metoda, koncept ali metodološki model; Bizjak, 2008; Prah, 2012; The DPSIR framework, 2018). Gre za ponovljiv (ciklični) postopek določanja stanja vodnih teles, ki vključuje tudi opredelitev človekovih pritiskov na vodna telesa (Bizjak, 2008; Howe, White, 2002). DPSIR model vključuje analizo gonilnih sil (angl. Driving forces), obremenitev (angl. Pressures), stanja (angl. State), vplivov (angl. Impacts) in odzivov (angl. Responses). DPSIR za ugotavljanje stanja na področju okolja je oblikovala in jo tudi sicer uporablja Evropska agencija za okolje (Kovač, Kušar, Rejec Brancelj, 2014).

Slovenija je vsebino evropske Vodne direktive povzela leta 2002 v Zakonu o vodah (Zakon o vodah, 2002). V skladu z evropskim pristopom načrtovanja in upravljanja porečij je izdelala osrednji dokument načrtovanja in upravljanja porečij, poimenovan Načrt upravljanja voda za vodni območji Donave in Jadranskega morja za obdobje 2009-2015 (Načrt upravljanja voda za vodni območji Donave in Jadranskega morja ..., 2011). Sprejeta sta že tudi načrta upravljanja voda za obe vodni območji za obdobje 2016-2021 (Načrt upravljanja voda, 2018).

Načrti upravljanja vodnih območij so kljub upoštevanju obremenitev, ki jih za vodna telesa pomenijo človekove dejavnosti, sektorski dokument. Zaradi potrebe po celovitejši geografski obravnavi porečij so avtorji strokovne pristope k oblikovanju načrtov upravljanja voda, predvidenih z Vodno direktivo, dopolnili. Brečko Grubar (2006) je na podlagi DPSIR modela oblikovala geografski metodološki pristop za načrtovanje 
trajnostnega upravljanja vodnih virov. Bricelj (2007) je opozoril na potrebo po opredelitvi najpomembnejših regionalnih hidrogeografskih značilnosti porečij kot osnove za geografski koncept upravljanja voda v Sloveniji. Frantar (2011) je opredelil vlogo geoinformacijske podpore pri analizi gonilnih sil na vodnih telesih. Prah (2012) je oblikoval geografski pristop celostnega upravljanja vodnih virov, ki temelji na geografski analizi prostorskih značilnosti porečja ter na delitvi porečja na posamezna hidrografska območja. Izhodiščno stanje okolja je preučil z integralnim geografskim modelom, ki prav tako izhaja iz metode DPSIR, vendar se je omejil le na dejavnike pritiskov na vodne vire, analizo pritiskov na vodne vire, ranljivost vodnih virov, stanje in težnje kakovosti vodnih virov, vplive kakovosti vodnih virov in odzive politik.

Avtorji geografskih strokovnih analiz porečij, ki izhajajo iz DPSIR modela, v njih obravnavajo predvsem vodne vire oziroma načrtovanje in upravljanje porečij z vidika voda. Za doseganje trajnostnega prostorskega razvoja porečij pa bi bil potreben celovitejši prostorsko-načrtovalski pristop z upoštevanjem širših razsežnosti razvoja. Na pomanjkljivost takšnih pristopov opozarja tudi Prah (2012), ki izpostavlja premajhno konkretizacijo prostorskega opredeljevanja ukrepov ter potrebo po jasnejši vključitvi drugih dejavnikov pri obravnavi porečij, na primer poselitvenega vzorca.

\subsection{Sistem prostorskega načrtovanja v Sloveniji}

Prostorsko načrtovanje je interdisciplinarna dejavnost, s katero se ob upoštevanju varstvenih zahtev, razvojnih interesov ter razvojnih možnosti določajo pogoji za razvoj dejavnosti v prostoru in njihovo razmestitev ter pogoji za umestitev načrtovanih objektov $\mathrm{v}$ prostor in njihovo izvedbo (Poročilo o ..., 2016).

Sistem prostorskega načrtovanja v Sloveniji temelji na strateških prostorskih razvojnih dokumentih ter na hierarhično urejenih prostorskih aktih na državni, regionalni in lokalni (občinski) ravni (Prostorski planski inštrumenti ..., 2002). Država je pristojna za določanje ciljev prostorskega razvoja na nacionalni ravni ter za določanje izhodišč in usmeritev za načrtovanje prostorskih ureditev na vseh ravneh. Ključni strateški razvojni dokument, ki usmerja razvoj v prostoru, je Strategija prostorskega razvoja Slovenije, ki poleg ciljev prostorskega razvoja ter zasnove prostorskega razvoja Slovenije s prednostnimi nalogami opredeljuje tudi usmeritve za prostorski razvoj na regionalni in lokalni ravni (Strategija prostorskega razvoja Slovenije, 2004).

V Sloveniji se prostorsko načrtovanje poleg državne ravni izvaja le še na občinski ravni (Prostorski planski inštrumenti ..., 2002). Na regionalni ravni so bile v preteklosti v vseh obdobjih veljavnosti posameznih zakonov predvidene nekatere oblike medobčinskega sodelovanja na področju prostorskega načrtovanja, vendar do veljavnih regionalnih prostorskih načrtov ni prišlo, kljub temu da se odsotnost regionalne ravni prostorskega načrtovanja pogosto omenja kot eden od ključnih izzivov na področju prostorskega načrtovanja v Sloveniji (Prostorski planski inštrumenti ..., 2002).

Leta 2018 je stopila v veljavo nova prostorska zakonodaja. Zakon o urejanju prostora (ZUreP-2) med prostorskimi strateškimi akti opredeljuje tudi regionalni prostorski plan. Zaradi harmonizacije regionalnega razvojnega (regionalni razvojni programi) in 
regionalnega prostorskega načrtovanja se bodo regionalni prostorski plani oblikovali za območja razvojnih regij v Sloveniji (Zakon o urejanju ... 2017), kar pa ne rešuje nujno problematike trajnostnega prostorskega razvoja problemsko zaokroženih geografskih enot, na primer posameznih porečij.

To dokazujejo izkušnje iz Vipavske doline, kjer Svet za Vipavo koordinira usklajena prizadevanja občin na območju porečja Vipave za reševanje razvojnih izzivov, predvsem poplavne ogroženosti in načrtovanja zelene infrastrukture (Ožbot, 2015), česar pa ne bi bilo mogoče tako učinkovito nasloviti z regionalnim prostorskim planom za Goriško razvojno regijo, ki zajema tudi Posočje in Idrijsko-Cerkljansko območje s specifičnimi razvojnimi izzivi.

Pri pripravi prostorskih dokumentov so strokovne analize podlaga za oblikovanje prostorskih rešitev, vključevanje relevantnih deležnikov (nosilcev urejanja prostora, javnosti) ter sprejemanje končnih odločitev o prihodnjem prostorskem razvoju. Analize so najpogosteje umeščene v naslednje temeljne vsebinske okvire (Černe, 2004, str. 35):

1. analiza stanja in teženj, ki opisuje obstoječe in prihodnje prostorske razmere in pogoje;

2. ocena stanja, vključno z relativnim pomenom prostorskih problemov ali stopnjo doseganja ciljev, ter dejavniki, ki povzročajo prostorske probleme;

3. vrednote, ki opredeljujejo cilje, probleme ali vprašanja in prednostne naloge;

4. politika, ki opisuje načela za usmerjanje prostorskega načrtovanja, reševanje problemov in usmerjanje razvoja.

Strokovne analize v prostorskem načrtovanju tako zajemajo (Černe, 2005, str. 124):

1. analizo stanja,

2. oceno stanja,

3. razvojne možnosti,

4. prostorske vizije,

5. variante prostorskega razvoja.

Takšen metodološki pristop k pripravi strokovnih podlag za prostorske dokumente je lahko osnova za nadaljnje korake v prostorskem načrtovanju, ki so normativno urejeni (predpisani z zakonodajo in podzakonskimi dokumenti), bil pa je že preizkušen pri pripravi strokovnih gradiv za Strategijo prostorskega razvoja Slovenije iz leta 2004 (Černe, 2005, str. 123-124).

\section{ZASNOVA GEOGRAFSKEGA PRISTOPA ZA PRIPRAVO STROKOVNIH PODLAG ZA PROSTORSKO NAČRTOVANJE $\checkmark$ POREČJIH}

S povezavo DPSIR modela, ki se uporablja kot analitični pristop na področju načrtovanja upravljanja voda, in strokovnih analiz, ki se uporabljajo pri zasnovi prostorskih dokumentov, želimo na metodološki ravni prispevati $\mathrm{k}$ tesnejši povezanosti upravljanja voda s prostorsko-načrtovalskim pristopom. $\mathrm{Z}$ oblikovanjem enotnega pristopa $\mathrm{k}$ izdelavi 
strokovnih analiz je omogočen celovitejši pogled na stanje v prostoru, ki upošteva neločljivo povezanost potreb po varovanju voda in dinamike prostorskega razvoja s ciljem trajnostnega prostorskega razvoja v porečjih. Pristop k izdelavi strokovnih podlag za načrtovanje trajnostnega prostorskega razvoja v porečjih zaradi upoštevanja večjega števila prostorskih elementov imenujemo " geografski pristop k izdelavi strokovnih podlag za prostorsko načrtovanje v porečjih«. Ta upošteva vse prostorske elemente v porečju s poudarkom na ohranjanju vodnih virov in se od pristopov, predstavljenih v prejšnjem poglavju, razlikuje v celovitosti obravnave porečja z vsemi geografskimi značilnostmi in razvojnimi procesi in se ne omejuje izključno na obravnavo vodnih virov. Tako oblikovane

Preglednica 1: Primerjava analitičnih faz DPSIR modela in strokovnih analiz v prostorskem načrtovanju ter predlaganega geografskega pristopa $k$ izdelavi strokovnih podlag za prostorsko načrtovanje v porečjih.

Table 1: Comparison of analytical phases of the DPSIR model, the professional analysis in spatial planning and the proposed geographical approach to professional analysis in river basin spatial planning.

\begin{tabular}{|c|c|c|}
\hline DPSIR model & $\begin{array}{l}\text { Strokovne analize } \\
\text { v načrtovanju }\end{array}$ & Geografski pristop k izdelavi strokovnih podlag \\
\hline $\begin{array}{l}\text { Vhodni podatki } \\
\text { Osnovno stanje porečja } z \\
\text { vidika voda, predstavitev in } \\
\text { določitev vodnih teles }\end{array}$ & \multirow[t]{3}{*}{ Analiza stanja } & $\begin{array}{l}\text { Geografske značilnosti porečja in členitev } \\
\text { Temeljna geografska predstavitev porečja z } \\
\text { naravnogeografskimi in družbenogeografskimi značilnostmi } \\
\text { Členitev porečja na manjše prostorsko-načrtovalske enote }\end{array}$ \\
\hline $\begin{array}{l}\text { Gonilne sile } \\
\text { Človekove dejavnosti } \\
\text { (industrija, promet, } \\
\text { turizem) }\end{array}$ & & \multirow{2}{*}{$\begin{array}{l}\text { Analiza stanja prostora } \\
\text { Obravnavani aktualni prostorski procesi in problemi, } \\
\text { ki izhajajo iz geografskih značilnosti in dosedanjega } \\
\text { prostorskega razvoja; rezultat vseh dejavnosti v } \\
\text { prostoru (morfologija in funkcija naselij, gospodarstvo, } \\
\text { infrastruktura, raba naravnih virov) in njihovih vplivov, } \\
\text { pozitivni in negativni vplivi na prostor }\end{array}$} \\
\hline $\begin{array}{l}\text { Obremenitve } \\
\text { Neposredne obremenitve } \\
\text { okolja s strani gonilnih sil }\end{array}$ & & \\
\hline $\begin{array}{l}\text { Stanje } \\
\text { Stanje v okolju: raven } \\
\text { onesnaženosti, raba in } \\
\text { količina razpoložljivih } \\
\text { naravnih virov }\end{array}$ & Ocena stanja & $\begin{array}{l}\text { Ocena stanja prostora } \\
\text { Opredeljuje trenutno stanje prostora in prostorskih } \\
\text { struktur glede na želeno stanje - trajnostni prostorski } \\
\text { razvoj }\end{array}$ \\
\hline $\begin{array}{l}\text { Vplivi } \\
\text { Učinki spremenjenega } \\
\text { okolja na živa bitja }\end{array}$ & \multirow[t]{2}{*}{$\begin{array}{l}\text { Prostorske } \\
\text { razvojne možnosti, } \\
\text { prostorske } \\
\text { vizije, variante } \\
\text { prostorskega } \\
\text { razvoja }\end{array}$} & $\begin{array}{l}\text { Model prostorskega razvoja - prostorske razvojne } \\
\text { možnosti, vizija } \\
\text { Opredeljujemo možnosti nadaljnjega prostorskega } \\
\text { razvoja na podlagi poznanih dejstev o prostoru (procesov, } \\
\text { problemov, omejitev) }\end{array}$ \\
\hline $\begin{array}{l}\text { Odzivi } \\
\text { Odgovori družbe na } \\
\text { okoljske probleme } \\
\text { (ukrepi države, odzivi } \\
\text { posameznikov ipd.) }\end{array}$ & & $\begin{array}{l}\text { Usmeritve, ukrepi } \\
\text { Usmeritve za prostorsko načrtovanje vseh prostorskih } \\
\text { elementov z namenom doseganja trajnostnega } \\
\text { prostorskega razvoja }\end{array}$ \\
\hline
\end{tabular}


strokovne podlage so pomembno izhodišče za prostorsko načrtovanje na regionalni in občinski ravni, saj postavljajo v ospredje trajnostni prostorski razvoj problemsko širših zaključenih območij - porečij, kar bo zaradi pričakovanih učinkov podnebnih sprememb na vodno dinamiko še posebej dragoceno.

Povezavo DPSIR modela (Kovač, Kušar, Rejec Brancelj, 2014) in strokovnih analiz v planiranju (Černe, 2005) omogoča soroden pristop pri obravnavi prostora (preglednica 1). Pri oblikovanju predlaganega pristopa $\mathrm{k}$ strokovnim analizam v porečjih smo izhajali tudi iz Prahovega geografskega pristopa celostnega upravljanja vodnih virov, ki poudarja pomen uvodne geografske analize prostorskih značilnosti porečja ter delitev porečja na posamezna homogena hidrografska območja (Prah, 2012).

Osnovni elementi geografskega pristopa $\mathrm{k}$ izdelavi strokovnih podlag za prostorsko načrtovanje v porečjih so (slika 1$)$ :

1. geografske značilnosti porečja,

2. členitev porečja na manjše prostorsko-načrtovalske enote,

3. analiza stanja prostora,

4. ocena stanja na področju prostorskih procesov in problemov,

5. oblikovanje modela prostorskega razvoja porečja kot vizualizacija ključnih usmeritev za trajnostni prostorski razvoj porečja,

6. oblikovanje usmeritev in ukrepov za doseganje trajnostnega prostorskega razvoja v porečju.

Prvi element geografskega pristopa k izdelavi strokovnih podlag za prostorsko načrtovanje v porečjih je opredelitev geografskih značilnosti porečja. Gre za opredelitev temeljnih naravnogeografskih (relief, podnebje, vode, prsti) in družbenogeografskih (prebivalstvo, gospodarska struktura, raba zemljišč, infrastruktura) značilnosti. Splet naravnogeografskih in družbenogeografskih elementov oblikuje porečje v celoto. Njihova povezanost in medsebojno součinkovanje ustvarjata specifike vsakega porečja, ki jih ne moremo neposredno prenesti v sosednje, še manj v oddaljeno porečje. Spoznanja o geografski strukturi porečja lahko po zgledu Praha (2012) zaradi notranje raznolikosti $\mathrm{v}$ prostorski strukturi in za večjo učinkovitost predlaganih razvojnih usmeritev in ukrepov vodijo do odločitve o členitvi porečja na manjše prostorske enote, ki služijo kot prostorsko-načrtovalske enote. Usmeritve in ukrepi so tako bolje prilagojeni specifičnim (sub)regionalnim razmeram. Ključni kriteriji za členitev porečja so hidrografske značilnosti in značilnosti poselitve.

Analiza stanja prostora je pomembna z vidika razumevanja aktualnih prostorskih procesov in problemov, ki izhajajo iz geografskih značilnosti. Analiza kaže obstoječe stanje prostorskih struktur in opozarja na prostorske probleme oziroma neželene razmere. Temelji na dejstvih o prostoru. Prostorski procesi in problemi (na primer razvoj naselij in infrastrukture, degradirana območja, poplave) oblikujejo trenutno stanje prostora in vplivajo na možnosti nadaljnjega razvoja porečja. Odvijajo se bodisi v celoti ali delno znotraj porečja bodisi zunaj njega, njihov potek pa vpliva na stanje prostora v porečju.

$\mathrm{Z}$ oceno stanja prostora se ovrednoti ugotovljeno stanje prostora. To pomeni opredelitev do trenutnih prostorskih procesov - ti so dobri oziroma negativni - ter relevantnost 
Slika 1: Shema geografskega pristopa k izdelavi strokovnih podlag za prostorsko načrtovanje $v$ porečjih za doseganje trajnostnega prostorskega razvoja v porečjih.

Figure 1: The structure of the geographical approach to professional analysis in river basin spatial planning.

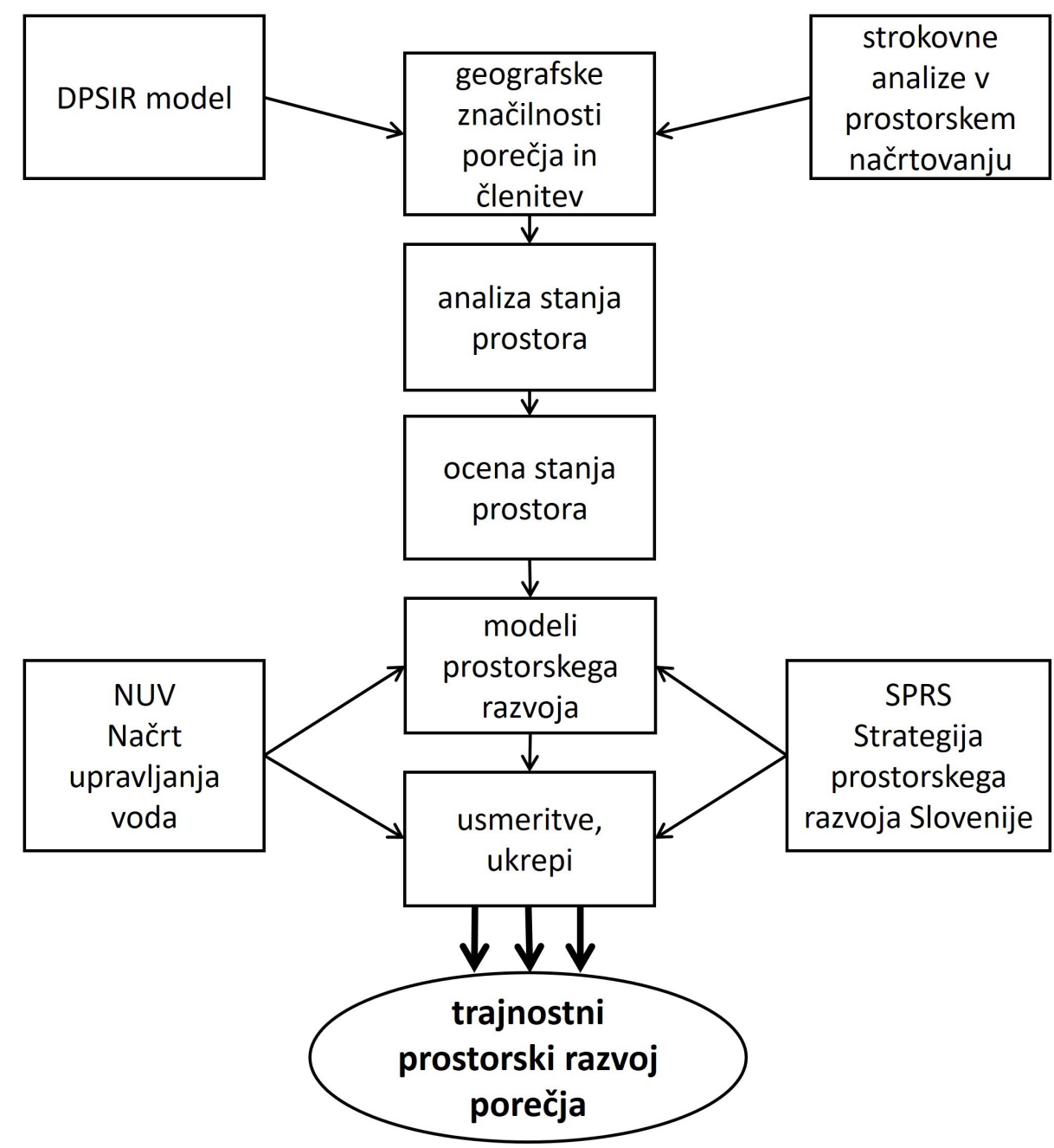

prostorskih problemov za nadaljnji prostorski razvoj. Iz ocene stanja prostora izhaja odločitev o reševanju tistih prostorskih vprašanj, ki jih označimo kot ključna za doseganje trajnostnega prostorskega razvoja v porečjih.

$\mathrm{Na}$ oblikovanje modela ali več modelov prostorskega razvoja vplivajo pretekli, trenutni in predvideni prostorski procesi znotraj in zunaj porečja, pa tudi drugi dejavniki, 
na primer družbene, gospodarske, socialne, institucionalne, pravno formalne razmere in zahteve (nadrejeni oziroma strateški razvojni dokumenti - v primeru obravnave porečij načrt upravljanja voda in Strategija prostorskega razvoja Slovenije, v prihodnosti tudi regionalni prostorski plani) ter tehnično-tehnološke možnosti. Modeli prikazujejo pričakovan prostorski razvoj glede na trenutno stanje ob upoštevanju prostorskih danosti ter omejitev. V viziji prostorskega razvoja predstavimo stanje prostora $\mathrm{v}$ prihodnosti, kakršnega želimo doseči v procesu prostorskega načrtovanja. Vizija kaže sliko glavnih prostorskih struktur porečja in njihovih medsebojnih razmerij z željo po trajnostnem prostorskem razvoju.

Zadnji element pristopa so usmeritve in predlogi ukrepov. Ti temeljijo na geografskih značilnostih, analizi in oceni stanja prostora ter prostorskih razvojnih možnostih porečja in opredeljujejo pot k trajnostnemu prostorskemu razvoju porečja. Nanašajo se na posamezne prostorske elemente in celotno porečje. Namenjeni so lažji pripravi in izvedbi konkretnih prostorsko načrtovalskih ukrepov in projektov v porečju, ki se lahko udejanjijo v prostorskih načrtih na lokalni in regionalni ravni.

\section{UPORABA GEOGRAFSKEGA PRISTOPA NA PRIMERU POREČJA KOKRE}

Predlagani geografski pristop k izdelavi strokovnih podlag za prostorsko načrtovanje v porečjih smo uporabili na primeru porečja Kokre. Vsak element geografskega pristopa je v podpoglavjih vsebinsko nadgrajen in naslavlja aktualna prostorsko-razvojna vprašanja porečja, v zadnjem podpoglavju pa so predlagane strateške usmeritve za doseganje trajnostnega prostorskega razvoja porečja Kokre.

\section{I Geografske značilnosti porečja Kokre in členitev na prostorsko- -načrtovalske enote}

Porečje Kokre in njegove naravnogeografske značilnosti so preučevali različni avtorji. Melik $(1954,1959)$ ga je obravnaval v monografijah o Sloveniji, pleistocensko poledenitev je preučil Meze (1999), Polajnar (1957) je opisal geografske značilnosti doline Kokre, Perko (1987a, 1987b, 1992) je obravnaval tipe pokrajin in prebivalstvo. Družbenogeografskim značilnostim porečja Kokre, zlasti Kranja z okolico, so se posvečali Pak (1995, 2005), Slavčeva (1997) in Rebernik (2013). Območje je doživelo geografsko obravnavo tudi na Zborovanju slovenskih geografov na Bledu leta 2013.

Porečje Kokre meri $224 \mathrm{~km}^{2}$ in je sestavljeno iz dveh izrazitih delov. Zgornji ali alpski del (do Preddvora) je hribovit, spodnji del do izliva Kokre v Savo je ravninski. V zgornjem delu prevladuje erozijski tip rečnega reliefa, v spodnjem pa akumulacijski (Perko, 1992). Kokra je alpska reka z večinsko hudourniškim značajem, ki pri Kranju dobi glavni pritok Rupovščico. V prodnih in konglomeratnih terasah ravninskega dela porečja so večje količine talne vode. $\mathrm{V}$ hladni polovici leta je v ravninskem delu porečja pogost pojav temperaturne inverzije $\mathrm{z}$ radiacijsko meglo. Nasprotno ima termalni pas na prehodu $\mathrm{v}$ hriboviti del ugodnejše podnebne razmere z višjimi povprečnimi temperaturami, manjšo 
temperaturno amplitudo in boljšo osončenostjo (Ogrin, Vysoudil, Ogrin, 2013; Ogrin, Koželj, Vysoudil, 2016). Naravna vegetacija je gozd, ki zavzema večino ozemlja v porečju. Porečje je razdeljeno med 7 občin: Jezersko, Preddvor, Kranj, Šenčur, Tržič, Naklo in Cerklje na Gorenjskem. V celoti je v porečju Kokre občina Jezersko, z veliko večino ozemlja tudi občina Preddvor. Ostale občine delno ležijo znotraj porečja Kokre: mestna občina Kranj s svojim severnim delom, občina Šenčur med naseljema Hotemaže in Milje, občina Naklo v delu Udin boršta, občini Tržič pripada skrajni zahodni del porečja, občini Cerklje na Gorenjskem pa le območje smučišča Krvavec. Leta 2017 je bilo v porečju 16.374 prebivalcev, upoštevajoč mesto Kranj, ki sicer ne leži v celoti v porečju Kokre, pa 53.927. Število prebivalcev se povečuje na račun spodnjega dela porečja. Gostota prebivalstva v porečju je leta 2017 znašala 73,1 prebivalca $/ \mathrm{km}^{2}$ (Draksler, 2015; SURS, 2018).

Porečje Kokre smo členili na prostorsko-načrtovalske enote (slika 2), ki delno sovpadajo s tipi pokrajin, ki jih je razločil Perko (1992) in so rezultat součinkovanja pokrajinskih sestavin porečja, vendar smo se pri členitvi na prostorsko-načrtovalske enote osredotočili predvsem na naslednje kriterije:

- intenzivnost rabe prostora (število prebivalcev in gostota poselitve, poselitveni vzorec);

- hidrografske značilnosti (tip vodotokov, vrste vodnih virov).

Razločili smo šest prostorsko-načrtovalskih enot:

1. Zgornji del porečja

Zajema povirni del Kokre s številnimi hudourniškimi pritoki in sega do konca doline pri Preddvoru. Značilna je razpršena poselitev v obliki samotnih kmetij in zaselkov in zelo nizka gostota poselitve (pod 10 prebivalcev $/ \mathrm{km}^{2}$ ).

2. Pobočja Kriške gore, Storžiča in Srednjega vrha

Tu se nahajajo pomembni viri za oskrbo s pitno vodo (v Gozdu, nad Povljami in Bašljem) ravninskega dela porečja in Srednje Gorenjske. Rečno mrežo večinoma sestavljajo povirni deli pritokov Rupovščice. Redka poseljena območja so v nižje ležečih delih na meji s termalnim pasom (naselje Gozd in posamezna počitniška bivališča), kjer se naklon površja nekoliko zmanjša.

3. Termalni pas

Termalni pas leži na prehodu hribovja v ravnino in ima najugodnejše podnebne razmere v porečju. Gre za območje z rastjo intenzitete rabe prostora in prebivalstva (več kot 180 prebivalcev $/ \mathrm{km}^{2}$ ). Zgornji rob termalnega pasu sega do meje naselij, kot so Senično, Golnik, Goriče, Trstenik, Bašelj, Mače. Območje prečkajo številni potoki v svojem srednjem toku.

4. Konglomeratne terase in terciarno gričevje

Gre za ravninski del porečja z nižjimi nadmorskimi višinami in manjšimi nakloni od termalnega pasu. Ta prostorska enota je prepredena s spodnjimi deli pritokov Rupovščice. Mokrotni travniki so retencijske površine ter skupaj z zavarovanimi območji in gozdom (Udin boršt, Brdo) dejavnik nižje gostote poselitve (okrog 50 prebivalcev/ $\mathrm{km}^{2}$ ) v sicer gručastih naseljih. 
5. Območje ob Kokri od Preddvora do Milj

Enoto sestavljajo suburbana naselja ob glavni prometnici Kranj-Jezersko. Gre za ravninski svet vzdolž reke Kokre z visoko gostoto poselitve (več kot 500 prebivalcev/ $\mathrm{km}^{2}$ ) in intenzivno rabo prostora (stanovanja, storitvena, obrtna in trgovska dejavnost).

6. Kranj s predmestnimi naselji

Je prostorska enota $\mathrm{z}$ največjo intenzivnostjo rabe prostora $\mathrm{v}$ porečju Kokre, največjim številom prebivalstva in gostoto poselitve (brez Kranja več kot 550 prebivalcev/ $\mathrm{km}^{2}$ ). Glavne hidrografske značilnosti območja so spodnji tok Rupovščice in Kokre z njunim sotočjem ter podzemna voda na Kranjskem polju.

\subsection{Analiza stanja in ocena stanja prostora}

Pri analizi in oceni stanja prostora smo izpostavili prostorske probleme in procese, ki vplivajo na možnost doseganja trajnostnega prostorskega razvoja v porečju Kokre.

Suburbanizacija je eden glavnih procesov, ki je narekoval prostorski razvoj porečja Kokre v novejšem času. Pak (2005) postavlja začetek suburbanizacije v okolici Kranja v sedemdeseta in osemdeseta leta 20 . stoletja, proces pa se nadaljuje še danes. Bivalna funkcija in druge dejavnosti se umikajo iz Kranja v obmestna naselja na njegovem ožjem vplivnem območju. Tam se povečuje število prebivalcev, površina pozidanih površin, spreminja se zaposlitvena struktura prebivalstva, povečuje se prometna obremenitev cest, ki povezujejo Kranj s sosednjimi naselji (Kerbler, Ravbar, 2013; Rus, Razpotnik Visković, Nared, 2013). Zgornjega dela porečja Kokre suburbanizacija, zaradi oddaljenosti, naravnogeografskih značilnosti in zmanjševanja tranzitnega pomena ceste, ni zajela. Prav tako ni opaznega povečanja dnevnega prometa, ki bi spremljal suburbanizacijo (Draksler, 2014; DRSC, 2018). Ohranja se avtohtona razpršena poselitev, sklenjeno zasnovo ohranja naselje Zgornje Jezersko. Cigale (2013) ugotavlja tudi zmanjšanje turističnega obiska na Jezerskem. Povsem drugačno dinamiko prostorskega razvoja doživlja t. i. termalni pas. Število prebivalcev se povečuje, naselja se širijo, prihaja do morfoloških in funkcijskih sprememb. Nekdaj kmetijska naselja postajajo spalna, prej zgoščena naselja z novogradnjami dobivajo razpršeno podobo, ponekod se pojavlja razpršena gradnja (Draksler, 2015).

Eden od prostorskih problemov v porečju je širjenje poselitve v nekaterih naseljih (Visoko, Hotemaže) na območjih poplavne nevarnosti. Na dveh tretjinah porečja je prisotna erozijska nevarnost. Intenzivnejši erozijski procesi se odvijajo v zgornjem delu porečja, deloma tudi $v$ termalnem pasu. V Kranju je prisoten problem degradiranih urbanih območij. Nastala so po propadu nekaterih večjih industrijskih podjetij. Nekdanji industrijski kompleksi so opuščeni ali pa so se v njih delno umestile druge dejavnosti. Z okoljskega vidika je problematično nekdanje odlagališče odpadkov v Tenetišah, saj še ni sanirano (Kerbler, Ravbar, 2013). V raziskavi smo prav tako ugotovili, da prihaja do obremenjevanja vodnih virov porečja zaradi njihove pretirane rabe in onesnaževanja. Narašča poraba pitne vode (Ravbar, Kovačič, 2013), odvzem vode iz Kokre in pritokov za gospodarske potrebe (male hidroelektrarne, zasneževanje smučišča na Krvavcu) občasno povzroči, da je pretok pod ekološko sprejemljivo mejo. Porečje ima nepopolno 
opremljenost s kanalizacijskim sistemom (do pred nekaj leti opremljenost nad $80 \%$ le v Kranju, kjer je bila zgrajena tudi nova čistilna naprava), kar ogroža kakovost površinskih in podzemnih voda v porečju. Stanje na tem področju se izboljšuje, saj je bilo v okviru projekta GORKI zgrajeno kanalizacijsko omrežje v delu Kranja, na Kokrici, Hotemažah

Slika 2: Členitev porečja Kokre na prostorsko-načrtovalske enote.

Figure 2: Subdivision of the Kokra basin into smaller spatial planning units.

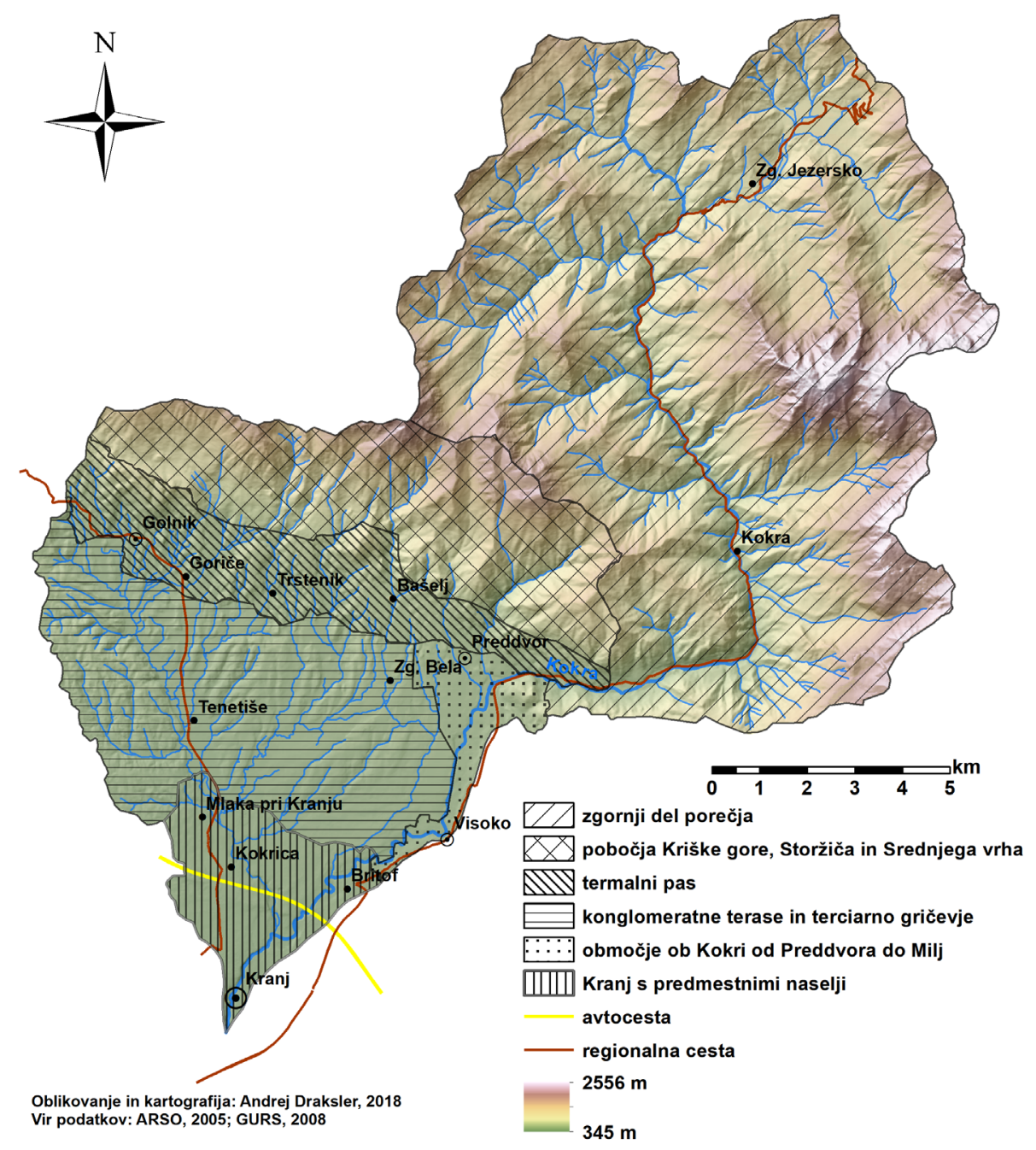


in Visokem, trenutno pa poteka gradnja še na Mlaki pri Kranju, v Britofu in Predosljah (Projekt GORKI ..., 2018). Prav tako je bilo v zadnjem obdobju zgrajeno kanalizacijsko omrežje na Zgornjem Jezerskem in nekaterih naseljih občine Preddvor. K večji zanesljivosti in učinkovitosti pri oskrbi s pitno vodo je pripomogel nov vodovod Bašelj-Kranj (Hanc, 2015). Površinske in podzemne vode so izpostavljene tudi kmetijskemu onesnaževanju in neprimernim posegom $v$ vodotoke. $V$ številnih naseljih so hiše locirane tik ob vodotokih, ki so na več mestih regulirani, struge pa obzidane. Pogosto je odlaganje odpadkov in različnega materiala v struge manjših vodotokov ali ob njih, vse to pa zmanjšuje retencijski potencial in povečuje poplavno ogroženost naselij. Splošno stanje vodnih virov v zgornjem delu porečja je boljše kot v drugih delih (Draksler, 2015).

\subsection{Model prostorskega razvoja porečja Kokre}

Glede na trenutne prostorske procese lahko pričakujemo, da se bo v zgornjem delu porečja ohranjala sedanja zasnova poselitve. Na ravninskih delih porečja vzdolž Kokre, na suburbanih območjih in v Kranju se nakazuje notranji razvoj naselij ali njihovo zaokroževanje. Tak razvoj je $\mathrm{z}$ vidika rabe prostora boljša rešitev od širjenja naselij na nove površine, ki ga lahko pričakujemo v naseljih termalnega pasu. Na tem območju se bo predvidoma nadaljevala gradnja enodružinskih hiš ter počitniških bivališč, ki se bodo delno preobražala v stalna bivališča. V suburbanih naseljih ter lokalnih središčih (Golnik, Preddvor, Visoko) se bodo krepile središčne dejavnosti. Predvsem v termalnem pasu gre zaradi širjenja pozidave pričakovati povečanje erozijske ogroženosti in pritiskov na vodne vire, saj številna naselja, kljub napredku projekta GORKI in sorodnih projektov, še nimajo ustreznega upravljanja z odpadnimi vodami. Predvidoma se bo izboljšala oskrba s pitno vodo v spodnjem delu porečja z novim vodovodom BašeljKranj ter zmanjšali pritiski na vodne vire po dokončanju kanalizacijskega sistema v večjih sklenjenih naseljih (Projekt GORKI ..., 2018), izboljšati pa bo treba upravljanje z odpadnimi vodami na območjih razpršene poselitve. Obremenitve zaradi rabe vode za gospodarske namene se bodo povečevale. Poplavna varnost se predvidoma ne bo spreminjala, saj je nadaljnja gradnja na območjih poplav prepovedana z veljavnimi prostorskimi akti občin (Draksler, 2015).

Predlagani model prostorskega razvoja porečja Kokre izhaja iz policentrične zasnove poselitvenega sistema s Kranjem kot glavnim prebivalstvenim in gospodarskim središčem z vplivnim območjem izven porečja Kokre. Dopolnjujejo ga naselja Golnik, Preddvor, Visoko in Zgornje Jezersko, ki imajo vlogo lokalnih zaposlitvenih središč tudi za okoliške prebivalce. Poselitev zgornjega dela porečja je redka, tamkajšnji prebivalci se delno zaposlujejo v Preddvoru. Gospodarski razvoj izhaja iz lokalnih naravnih virov: zlasti v zgornjem delu porečja je razvito gozdarstvo, kmetijstvo na samotnih kmetijah ter športnorekreacijski turizem. Naselja v porečju so kompaktna, med seboj so povezana z obstoječimi cestnimi povezavami. Naravno okolje je ohranjeno, vodni viri niso obremenjeni zaradi onesnaževanja ali prevelikega odvzema vode, vodotoki pa so sonaravno urejeni. Poselitev je odmaknjena od poplavno in erozijsko nevarnih ali plazljivih območij (Draksler, 2014). 


\subsection{Ključne usmeritve za nadaljnji trajnostni prostorski razvoj porečja Kokre}

Ob upoštevanju geografskih značilnosti porečja Kokre, dosedanjega prostorskega razvoja in prostorskih teženj smo oblikovali usmeritve za nadaljnji trajnostni prostorski

Slika 3: Predlogi za razvoj poselitve v porečju Kokre.

Figure 3: Proposed development of the settlement system in the Kokra Basin.

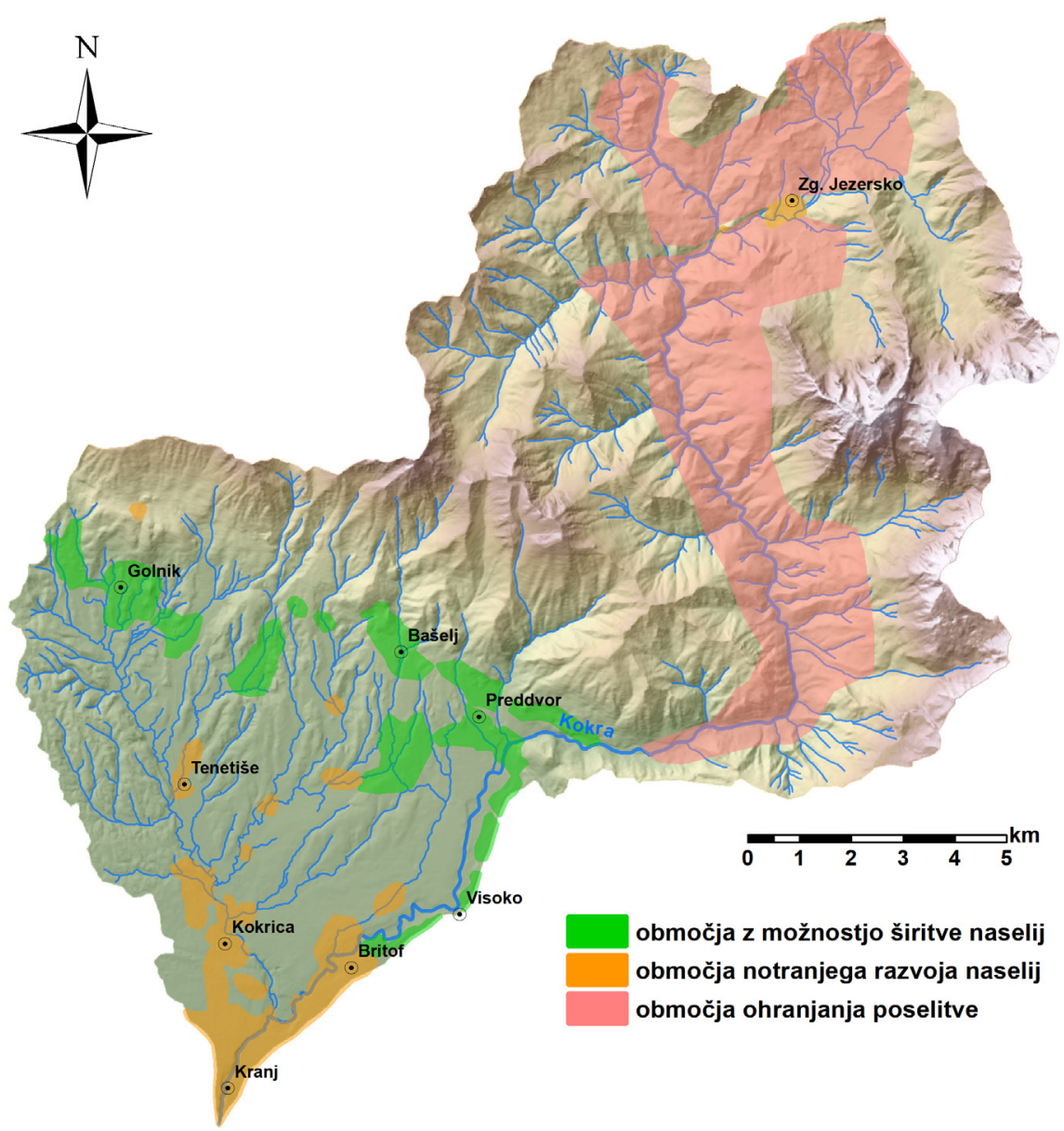


razvoj. Pri tem smo v pomembni meri izhajali iz priporočil Strategije prostorskega razvoja Slovenije (2004) za razvoj prostorskih sistemov na regionalni in lokalni ravni, ki smo jih prilagodili specifičnim prostorskim izzivom v porečju Kokre. Predlagane usmeritve se nanašajo tudi na načrta upravljanja voda za obdobje 2016-2021 (Načrt upravljanja voda, 2018).

Slika 4: Možnosti nadaljnjega prostorskega razvoja v porečju Kokre - prostorske omejitve. Figure 4: Possibilities for further spatial development in the Kokra Basin-spatial restrictions.

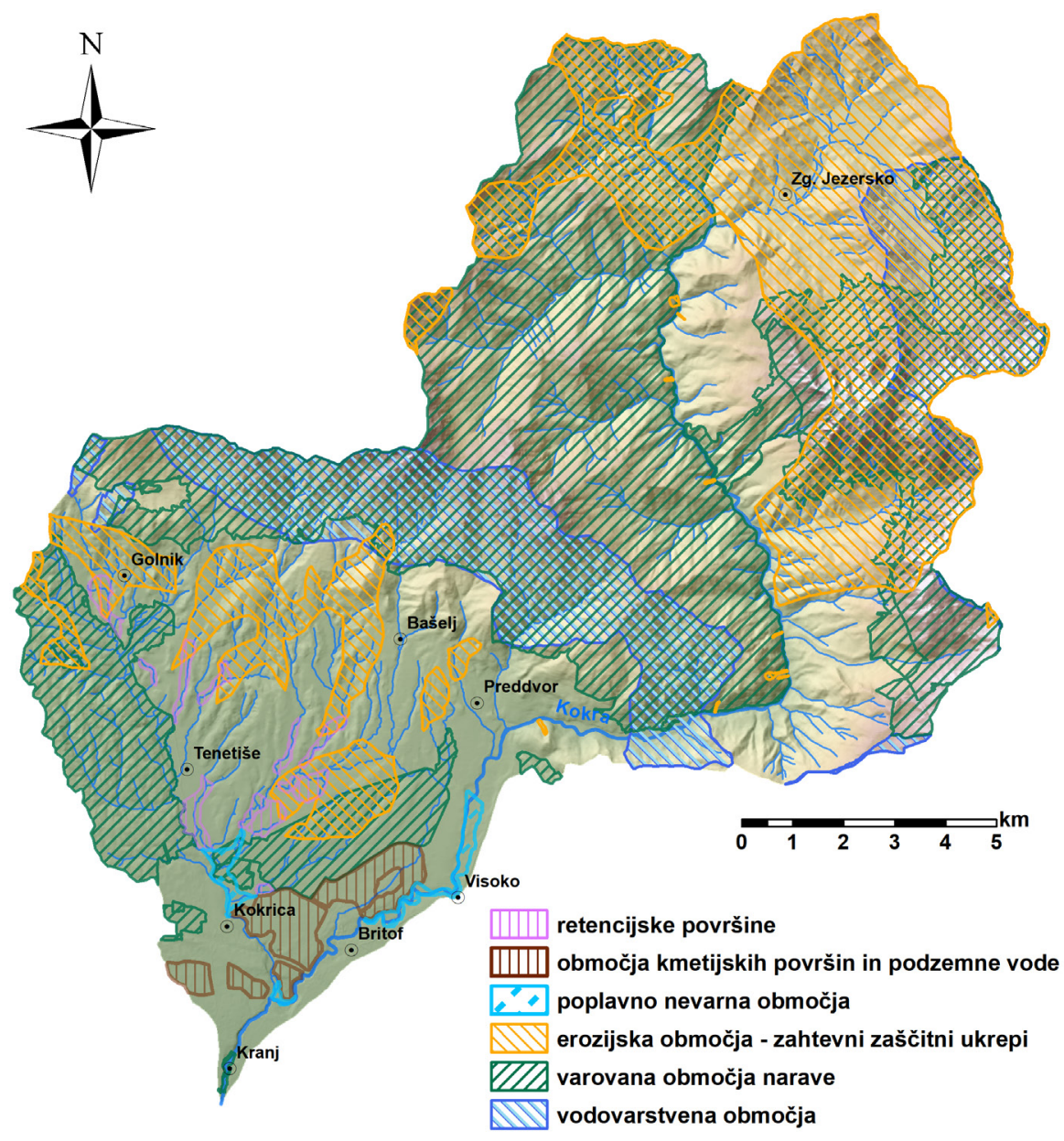

Oblikovanje in kartografija: Andrej Draksler, 2018

Vir podatkov: ARSO, 2005; GURS, 2008 
Usmeritve s področja poselitve. Nova poselitev v porečju naj se umešča na že poseljena območja z zgoščeno poselitvijo. S tem se izboljša izkoristek prostora, zmanjša stroške gradnje in vzdrževanja infrastrukture, preprečuje razpršena gradnja in ohranja poselitveni vzorec. V Kranju in suburbanih območjih je zato smiselno zaokroževanje obstoječih naselij in njihov notranji razvoj. S tem se obenem ohranja kmetijska zemljišča na Kranjskem polju. V termalnem pasu ter vzdolž Kokre med Preddvorom in Miljami je možna širitev poselitve ob predpostavki, da se poselitev ne širi na erozijsko aktivna ali poplavna območja. Zaradi omejenih prostorskih možnosti je v sedanjem obsegu zlasti treba ohranjati poselitev zgornjega dela porečja (slika 3). Širitev tamkajšnjih naselij tudi ni upravičena zaradi oddaljenosti od središč, povečevanja pritiskov na vodne vire in večjih posegov v prostor, ki bi bili potrebni za zagotavljanje infrastrukturne opremljenosti novih poselitvenih območij zgornjega dela porečja (slika 4).

Gospodarstvo naj se razvija na podlagi lokalnih naravnih virov. Lesne zaloge omogočajo ponoven razvoj gozdarstva in lesno-predelovalnih dejavnosti, vode pa so poleg pogonskega vira (žage) ali vira energije (hidroelektrarne) hkrati lahko turistični potencial. Prioritetnega pomena v porečju Kokre je sanacija degradiranih območij (v Kranju Savska cesta, Jelenčeva ulica, tovarna olj v Britofu), kamor se lahko s spremembo namenske rabe umesti nove dejavnosti, denimo trgovske ali druge storitvene dejavnosti, ki so v zadnjih letih v porastu. Povsod v porečju je nesprejemljivo širjenje naselij na poplavna, erozijska ali plazljiva območja.

Usmeritve s področja infrastrukture in krajine. Ohranjati je treba retencijsko vlogo mokrotnih travnikov ob pritokih Rupovščice (slika 4), ki so naravni zadrževalniki visokih voda in tako preprečujejo poplavljanje na območju Kranja. V porečju je potrebna nadaljnja celovita obravnava odpadnih voda (kanalizacijski sistem v gosteje poseljenem delu porečja, individualne čistilne naprave v zgornjem delu porečja), vzdrževanje in obnova vodovodnih sistemov ter ustrezno varovanje območij vodnih zajetij v naselju Gozd, nad Bašljem in Povljami. Pri rabi vode za gospodarske namene naj se zagotavlja zadostna količina vode za nemoteno ohranjanje vodnih habitatov in omogoči migracije rib po strugi, odvzeto vodo pa naj se čim hitreje vrne v vodotok. Nad odvzemom vode za male hidroelektrarne in napajanje ribnikov Brdo je zato potreben ustrezen nadzor.

\section{SKLEP}

V prispevku smo prikazali možen pristop za pripravo strokovnih podlag za prostorsko načrtovanje $\mathrm{v}$ okviru porečij, ki v primerjavi s pristopom, ki ga predvideva evropska Vodna direktiva, v večji meri upošteva širši prostorski vidik načrtovanja in ne zgolj okoljevarstvenega, vezanega na vodne vire. Z uporabljenim pristopom smo poskušali zajeti in upoštevati vse ključne prostorske elemente in dejavnike v porečju, kar je ključnega pomena za doseganje njegovega trajnostnega prostorskega razvoja.

Na podlagi teoretičnih izhodišč (porečje kot prostorska enota za prostorsko načrtovanje, upravljanje voda, izdelava strokovnih analiz v prostorskem načrtovanju) smo oblikovali pristop, ki združuje DPSIR model, uporabljen pri načrtovanju upravljanja voda, ter koncept strokovnih analiz v prostorskem načrtovanju. Pristop smo po zgledu Praha (2012) 
zaradi celovitejše strokovne obravnave porečja (upoštevanja večjega števila prostorskih dejavnikov, a s poudarkom na ohranjanju vodnih virov), poimenovali »geografski pristop $\mathrm{k}$ izdelavi strokovnih podlag za prostorsko načrtovanje v porečjih«. Za testiranje pristopa smo izbrali porečje Kokre.

Prednost obravnave manjših porečij je v možnosti večje natančnosti in izvedljivosti predlaganih ukrepov in usmeritev za prihodnji razvoj v porečju, obenem pa se odražajo v širšem merilu, saj je tudi manjše porečje del povezanega sistema porečij različnih hierarhičnih stopenj.

$\mathrm{V}$ analizi stanja in oceni stanja porečja Kokre smo ugotovili različno dinamiko prostorskih procesov v posameznih delih porečja, zato je delitev na manjše prostorske enote nujni sestavni del pristopa. Največje prostorske spremembe z intenzivno prostorsko širitvijo naselij se namreč ne odvijajo na suburbanih območjih v okolici Kranja, temveč v enoti porečja, poimenovani Termalni pas.

Največji izziv predlaganega pristopa k načrtovanju trajnostnega prostorskega razvoja je njegova vključitev v normativni sistem prostorskega načrtovanja v Sloveniji. V primeru prostorskega načrtovanja v porečjih gre za regionalno raven načrtovanja. Kljub predvideni izdelavi regionalnih prostorskih planov za razvojne regije v Sloveniji (pa tudi zaradi njih), so potrebni inovativni pristopi, ki omogočajo strateški razvojni pogled na sklenjena problemska območja, ki združujejo večje število občin. Strateško prostorsko načrtovanje v okviru porečij zato vidimo kot priložnost za naslavljanje izzivov trajnostnega prostorskega razvoja, ki presegajo zmožnosti posameznih občin, pa tudi sklenjenih problemskih območij znotraj razvojnih regij. Pri tem je ključna interdisciplinarnost, široko družbeno, strokovno, medsektorsko soglasje in soglasje občin znotraj porečja, ki bi bile vključene v pripravo strategije ali strateškega prostorskega načrta porečja, občine pa bi prenesle dogovorjene usmeritve prostorskega razvoja porečja v lokalno okolje preko občinskih prostorskih načrtov in konkretnih prostorskih ukrepov oziroma ureditev. Da je to mogoče, dokazuje Svet za Vipavo, ki povezuje občine v porečju Vipave z namenom reševanja širših prostorskih izzivov.

Pri obravnavi prostorskih razvojnih vprašanj v porečjih mora sodelovati tudi širša zainteresirana javnost. Predlagani pristop je metodološko orodje za izdelavo strokovnih podlag, ki je osnova za vključevanje nosilcev urejanja prostora in javnosti v naslednjih fazah strateškega prostorskega načrtovanja $\mathrm{v}$ porečjih. $\mathrm{Z}$ upoštevanjem mnenj stroke, uporabnikov, upravljavcev, društev in posameznikov, ki poznajo dejansko stanje v prostoru, se lahko doseže višja stopnja konsenza s pripravljavci prostorskih dokumentov. V procesu načrtovanja ne sme manjkati ozaveščanje najširšega kroga prebivalcev, bodisi o pripravi posameznih ukrepov ali o širši problematiki prostorskega razvoja v porečju. Za doseganje trajnostnega prostorskega razvoja v prihodnosti morajo viziji trajnostnega prostorskega razvoja porečja slediti vsi prebivalci.

Predlagani pristop k izdelavi strokovnih podlag za prostorsko načrtovanje v porečjih je prenosljiv na druga večja ali manjša porečja. Uporabljeni pristop se namreč s preučitvijo prostorskih razmer in procesov prilagaja vsakemu porečju posebej. 


\section{Literatura in viri}

ARSO [Agencija Republike Slovenije za okolje]. 2005. Vodotoki Slovenije. Ljubljana. Arhiv Oddelka za geografijo.

Bizjak, A., 2008. Vodno načrtovanje in načrti upravljanja voda. Dela, 30, str. 101-121.

Brečko Grubar, V., 2006. Trajnostno sonaravno gospodarjenje z vodnimi viri v porečju Kamniške Bistrice. Doktorska disertacija. Ljubljana, Filozofska fakulteta, Oddelek za geografijo, 121 str.

Bricelj, M., 2007. Geografske zasnove za upravljanje z vodnimi viri Slovenije. Doktorska disertacija. Ljubljana, Filozofska fakulteta, Oddelek za geografijo, 121 str.

Carter, J. G., 2007. Spatial planning, water and the Water Framework Directive: insights from theory and practice. The Geographical Journal. 173, 4, str. 330-342. DOI: 10.1111/j.1475-4959.2007.00257.x.

Cigale, D., 2013. Značilnosti turizma na Gorenjskem. V: Rogelj, B., Potočnik Slavič, I., Mrak, I. (ur.). Gorenjska v obdobju glokalizacije. Ljubljana, Znanstvena založba Filozofske fakultete, str. 239-252.

Černe, A., 2004. Analiza pred planom. V: Prosen, A. (ur). Prostorske znanosti za 21. stoletje. Ljubljana, Univerza v Ljubljani, Fakulteta za gradbeništvo in geodezijo, str. 31-40. Černe, A., 2005. Strokovne analize v prostorskem planiranju. Dela, 23, str. 115-166.

Danube River Basin District Management Plan - Update 2015. 2015. Vienna, International Commission for the Protection of the Danube River, 164 str. URL: https://www. icpdr.org/main/activities-projects/river-basin-management-plan-update-2015 (citirano 21. 10. 2018).

Danube River Basin District Management Plan. 2009. Vienna, International Commission for the Protection of the Danube River, 91 str. URL: http://www.icpdr.org/main/activities-projects/river-basin-management (citirano 5. 2. 2014).

Direktiva Evropskega parlamenta in sveta 2000/60/ES z dne 23. oktobra 2000 o določitvi okvira za ukrepe Skupnosti na področju vodne politike. 2000. URL: http://eur-lex.europa.eu/legal-content/SL/TXT/PDF/?uri=CELEX:02000L0060=20090625-\&fromEN (citirano 9. 5. 2014).

Draksler, A., 2014. Usmeritve za prostorsko načrtovanje v porečju Kokre. Diplomsko delo. Ljubljana, Univerza v Ljubljani, Filozofska fakulteta, Oddelek za geografijo, 111 str.

Draksler, A., 2015. Aktualni prostorski procesi in problemi v porečju Kokre. Geografski obzornik, 62, 1, str. 26-34.

DRSC. 2018. Podatki o prometu. Prometne obremenitve. Direkcija RS za ceste. URL: http://www.di.gov.si/si/delovna_podrocja_in_podatki/ceste_in_promet/podatki_o_ prometu/ (citirano 27. 10. 2018).

Frantar, P., 2011. Geoinformacijska zasnova preučevanja virov obremenjevanja porečij. Doktorska disertacija. Ljubljana, Filozofska fakulteta, Oddelek za geografijo, 278 str.

Gardiner, J., Thompson, K., Newson, M., 1994. Integrated watershed/river catchment planning and management: a comparison of selected Canadian and United Kingdom experiences. Journal of Environmental Planning and Management, 37, 1, str. 53-67. 
GURS [Geodetska uprava Republike Slovenije]. 2008. Digitalni model nadmorskih višin 12,5 m. Ljubljana.

Grindlay, A. L., Zamorano, M., Rodríguez, M. I., Molero, E., Urrea, M. A., 2011. Implementation of the European Water Framework Directive: Integration of hydrological and regional planning at the Segura River Basin, southeast Spain. Land use policy, 28, str. 242-256. DOI: 10.1016/j.landusepol.2010.06.005.

Haggett, P., 1972. Geography. A modern synthesis. New York, Harper \& Row, 483 str.

Hanc, M., 2015. Magistralni vodovod Bašelj-Kranj že z vsemi dovoljenji. URL: https:// www.delo.si/novice/slovenija/magistralni-vodovod-baseljndash-kranj-ze-z-vsemi-dovoljenji.html (citirano 27. 10. 2018).

Howe, J., White, I., 2002. The potential implications of the European Union Water Framework Directive on domestic planning systems: a UK case study. European Planning Studies, 10, 8, str. 1027-1038.

Jones, J., 1997. Global hydrology. Processes, resources and environmental management. Harlow, Longman, 399 str.

Kerbler, B., Ravbar, N., 2013. Suburbanizacija na območju Udin boršta in potreba po spremljanju vplivov na okolje. V: Rogelj, B., Potočnik Slavič, I., Mrak, I. (ur.). Gorenjska v obdobju glokalizacije. Ljubljana, Znanstvena založba Filozofske fakultete, str. 141-150.

Kidd, S., Shaw, D., 2007. Integrated water resource management and institutional integration: realising the potential of spatial planning in England. The Geographical Journal. 173, 4, str. 312-329.

Kovač, N., Kušar, U., Rejec Brancelj, I. Kazalci okolja v Sloveniji. O kazalcih. ARSO. URL: http://kazalci.arso.gov.si/?data=about (citirano 13. 5. 2014).

Kušar, S., 2006. The problem region as an instrument of regional policy: geographical perspectives. V: Henkel, R. (ur.): South Eastern European countries on their way to Europe - geographical perspectives. Leipzig, Leibniz-Institut Für Länderkunde (Heft 5), str. 111-124.

Mather, A., Chapman, K., 1995. Environmental resources. Burnt Mill, Longman Scientific \& Technical, 279 str.

Melik, A., 1954. Slovenija. Knj. 1. Slovenski Alpski svet. Ljubljana, Slovenska matica, 606 str.

Melik, A., 1959. Slovenija. Knj. 3. Posavska Slovenija. Ljubljana, Slovenska matica, 595 str. Meze, D., 1999. Sledi in učinki pleistocenske poledenitve v porečju Kokre. V: Roblek, T. (ur.). Preddvor v času in prostoru. Zbornik Občine Preddvor. Preddvor, Občina Preddvor, str. 33-41.

Načrt upravljanja voda za vodni območji Donave in Jadranskega morja za obdobje 2009-2015. 2011. Ministrstvo za okolje in prostor. 524 str. URL: http://www.mko. gov.si/fileadmin/mko.gov.si/pageuploads/podrocja/voda/nuv_donava_jadran_2015/ nacrt_upravljanja_voda.pdf (citirano 15. 5. 2014).

Načrt upravljanja voda. URL: http://www.mop.gov.si/si/delovna_podrocja/voda/nacrt_ upravljanja_voda/\#c18223 (citirano 22. 2. 2018).

Newson, M. D., 2009. Land, water and development. Sustainable and adaptive management of rivers. 3. izdaja. London, New York, Routledge, 441 str. 
Ogrin, D., Koželj, T., Vysoudil, M., 2016. Lokalno podnebje in topoklimatska karta Jezerskega. Dela, 45, str. 5-30. DOI: 10.4312/dela.45.1.5-30.

Ogrin, D., Vysoudil, M., Ogrin, M., 2013. Splošne podnebne razmere Gorenjske in lokalno podnebje Kamniške Bistrice. V: Rogelj, B., Potočnik Slavič, I., Mrak, I. (ur.). Gorenjska v obdobju glokalizacije. Ljubljana, Znanstvena založba Filozofske fakultete, str. 9-30.

Ožbot, A., 2015. Ko bo Vipava čista, bo spet zanimiva. URL: http://www.primorske.si/ Novice/Goriska/Ko-bo-Vipava-cista-bo-spet-zanimiva (citirano 3. 8. 2017).

Pak, M., 1995. Nekateri geografski elementi zgradbe Kranja. V: Sagadin, M. (ur.). Kranjski zbornik 1995. Kranj, Mestna občina Kranj, str. 149-159.

Pak, M., 2005. Prostorski razvoj Kranja v 20. stoletju. V: Štefe, D. (ur.). Kranjski zbornik 2005. Kranj, Mestna občina Kranj, str. 115-121.

Perko, D., 1987a. Pokrajina in raba tal v Pokokrju (primer računalniškega ugotavljanja povezanosti pokrajinskih prvin). Geografski zbornik, 27, str. 115-202.

Perko, D., 1987b. Povezanost prebivalstva v Pokokrju z nadmorsko višino in naklonom. Geografski vestnik, 59, str. 91-99.

Perko, D., 1992. Tipi pokrajin v porečju Kokre. Geografski obzornik, 39, 2, str. 25-32.

Petts, G., Bravard, J., 1996. A drainage Basin Perspective. V: Petts, G., Amoros, C. (ur.). Fluvial hydrosystems. London, Chapman \& Hall, 322 str.

Plut, D., 1999. Regionalizacija Slovenije po sonaravnih kriterijih. Geografski vestnik, 71, str. 9-25.

Polajnar, S., 1957. Dolina Kokre. Geografski vestnik, 27-28, str. 209-262.

Poročilo o prostorskem razvoju. 2016. Miklavčič, T. (ur). Ljubljana, Ministrstvo za okolje in prostor, Direktorat za prostor, graditev in stanovanja, 73 str.

Prah, K., 2012. Opportunities for incorporating geography into the river basin management. Dela, 37, str. 27-43. DOI: 10.4312/dela.37.2.27-43.

Projekt GORKI 2. sklop (2. faza) prinaša novo kanalizacijo na območja Mlake, Britofa in Predoselj. Gorenjski utrip. URL: http://gorenjski-utrip.si/projekt-gorki-2-sklop-2-faza-prinasa-novo-kanalizacijo-na-obmocja-mlake-britofa-in-predoselj/ (citirano 27. 10. 2018).

Prostorski planski inštrumenti - k učinkovitim rešitvam. 2002. Jančič, M. (ur). Ljubljana, Ministrstvo za okolje, prostor in energijo, Urad Republike Slovenije za prostorsko planiranje, 139 str.

Ravbar, N., Kovačič, G., 2013. Viri pitne vode na Gorenjskem: pregled preskrbe z vodo in upravljanja. V: Rogelj, B., Potočnik Slavič, I., Mrak, I. (ur.). Gorenjska v obdobju glokalizacije. Ljubljana, Znanstvena založba Filozofske fakultete, str. 165-174.

Rebernik, D., 2013. Prostorska in funkcijska preobrazba mestnega središča ter analiza novih območij storitvenih dejavnosti v Kranju. V: Rogelj, B., Potočnik Slavič, I., Mrak, I. (ur.). Gorenjska v obdobju glokalizacije. Ljubljana, Znanstvena založba Filozofske fakultete, str. 127-140.

Rejec Brancelj, I., Dobnikar Tehovnik, M., Uhan, J., 2011. Bistvene značilnosti nacionalnega načrta upravljanja voda 2009-2015 in izvajanje vodne direktive. V: Volfand, J. (ur.). Upravljanje voda v Sloveniji. Celje, Fit media, str. 8-19. 
Rus, P., Razpotnik Visković, N., Nared, J., 2013. Upravljanje območij z vidika sprememb funkcijskih zaledij centralnih krajev: primer Gorenjske. V: Rogelj, B., Potočnik Slavič, I., Mrak, I. (ur.). Gorenjska v obdobju glokalizacije. Ljubljana, Znanstvena založba Filozofske fakultete, str. 253-268.

Siegel, H., Schabl, A., 2008. Integrated land use planning and river basin management (ILUP). URL: http://www.interpraevent.at/palm-cms/upload_files/Publikationen/Tagungsbeitraege/2008_1_221.pdf(citirano 13. 10. 2016).

Slavec, A., 1997. Geografija Kranja. Doktorska disertacija. Ljubljana, Filozofska fakulteta, Oddelek za geografijo, 374 str.

Strategija prostorskega razvoja Slovenije. 2004. Ljubljana, Ministrstvo za okolje, prostor in energijo, Direktorat za prostor, Urad za prostorski razvoj, $75 \mathrm{str}$.

SURS. Podatkovni portal SI-STAT. Demografsko in socialno področje. URL: https:// pxweb.stat.si/pxweb/Database/Dem_soc/Dem_soc.asp (citirano 27. 10. 2018).

The DPSIR framework. URL: https://www.eea.europa.eu/publications/ 92-9167-059-6-sum/page002.html (citirano 22. 2. 2018).

Unwin, T., 1997. The place of geography. Harlow, Longman, 273 str.

Vrišer, I., 1992. Uvod v geografijo. Ljubljana, Filozofska fakulteta Univerze v Ljubljani, Oddelek za geografijo, 458 str.

Woltjer, J., Al, N., 2007. Integrating Water Management and Spatial Planning. Journal of the American Planning Association, 73, 2, str. 211-222. DOI: $10.1080 / 01944360708976154$.

Zakon o vodah. 2002. Uradni list RS, 67, str. 7648-7680.

Zakon o urejanju prostora (ZUreP-2). 2017. Uradni list RS, 61, str. 8255-8310.

\section{CONCEPT OF THE GEOGRAPHICAL APPROACH TO PROFESSI- ONAL ANALYSIS IN RIVER BASIN SPATIAL PLANNING}

\section{Summary}

Despite the approximation of water management and spatial planning in the Water Framework Directive, practice shows that water resources management takes place without due consideration of other elements in the area. Such an approach is problematic in terms of achieving sustainable spatial development of river basins, since it does not take into account that spatial processes in the river basin significantly affect the quantity and quality of water. In order to link the approaches of water management and spatial planning, we propose a more comprehensive - geographical approach to professional analysis relevant for river basin spatial planning. This approach combines the approach used in the water management planning (DPSIR model - analysis of driving forces, pressures, states, impacts and responses) and the professional analysis in spatial planning (analysis of the situation, assessment of the situation, development opportunities, spatial vision and variants of spatial development). In this way, we want, at the methodological level, to achieve a closer connection between the water management with a wider developmental aspect. 
The basic elements of the proposed professional approach are description of the river basin basic geographical characteristics, subdivision of the river basin to smaller spatial planning units, regional analysis of the territory of the river basin, assessment of spatial processes and problems, design of territorial development models of the river basin, and guidelines proposal for development policies and measures.

The first element of the geographical approach to the development of expert bases for river basin spatial planning is the description of the geographical characteristics of the river basin. The description contains basic natural-geographical (relief, climate, waters, soils) and socio-geographical (population, economic structure, land use, infrastructure) characteristics of the river basin. Based on the results of the first step, the river basin can be divided into smaller territorial units due to internal diversity in the spatial structure and in order to achieve greater efficiency of the proposed development policies and measures. The key criteria for the subdivision of the river basin are its hydrographical characteristics and settlement structure. Regional analysis covers several sets of analysis to show the existing situation of spatial structures and draws attention to spatial problems. Then, possibilities of further spatial development and spatial restrictions are assessed. Spatial processes and problems defined in the analytical phase of the process are then evaluated from the viewpoint of achieving sustainable spatial development in the river basin

The territorial development models of the river basin are influenced by past, current and predicted spatial processes inside and outside the basin, as well as other factors, for example, social, institutional, legal and formal conditions and requirements (superior or strategic development documents - in case of river basin management, a water management plan and strategic spatial development documents on the national and regional level). Models show the desired spatial development in the river basin. The last element of the approach are guidelines for development policies and measures together with suggestions for action.

The proposed geographical approach is a methodological tool for the preparation of professional analysis, which is the starting point for the involvement of spatial planning stakeholders and the public in the subsequent phases of strategic spatial planning in the river basins. During the planning process, it is necessary to raise awareness of the population, either at suggesting development measures or at dealing with the wider spatial development issues in the river basin. In order to achieve sustainable spatial development in the future, the vision of the sustainable spatial development of the basin must be a consensus of all inhabitants.

The proposed geographical approach to professional analysis in river basin spatial planning is transferable to larger or smaller river basins by adapting to their spatial conditions and processes.

(Translated by the authors) 